\title{
Genetic Variability, Heritability and Genetic Advance for Seed Yield in Fenugreek [Trigonella foenum-graecum (L.)]
}

\author{
D. K. Patel ${ }^{1}$, A. M. Patel ${ }^{2}$ and D. L. Sundesha ${ }^{3^{*}}$ \\ ${ }^{1}$ Department of Genetics and Plant Breeding, C.P. College of Agriculture, S.D. Agricultural \\ University, Sardarkrushinagar, [Gujarat], India \\ ${ }^{2}$ Seed Spices Research Station, ${ }^{3}$ College of Horticulture, S.D. Agricultural University, \\ Jagudan, [Gujarat], India \\ *Corresponding author
}

\section{A B S T R A C T}

Keywords

Fenugreek, GCV, PCV, Heritability and Genetic advance

Article Info

Accepted:

20 December 2020

Available Online:

10 January 2021
Forty genotypes of fenugreek were studied in a field experiment under North Gujarat condition. The observations on ten morphological traits were recorded. The analysis of variance indicated presence of considerable amount of variability in the population of genotypes studied. The highest GCV was observed for seed yield per plant, number of branches per plant, number of pods per plant and harvest index. High heritability along with high genetic advance as per cent of mean was observed for seed yield per plant, number of branches per plant, number of pods per plant, pod length and harvest index. High heritability estimates along with high genetic advance as per cent of mean indicates that variation for these characters is due to additive gene effects and consequently the scope is more for improving seed yield per plant, number of branches per plant, number of pods per plant and harvest index through selection.

\section{Introduction}

Fenugreek [Trigonella foenum-graecum (L.)] also known as Methi, is a small seeded selfpollinated, diploid annual plant with $2 \mathrm{n}=16$. Fenugreek was widely cultivated in warm temperate and tropical regions of the Mediterranean, Europe and Asia. India is the largest producer, exporter of seed spices in the world. During 2018- 19, fenugreek was cultivated in an area of 122 thousand hectares with an annual production of 189 thousand MT in India. [Anonymous (2019)]. Fenugreek is extensively used in both Indian Ayurvedic medicines and traditional Chinese medicines (Tiran, 2003). In herbal medicine it was used in the treatment of diabetes (Leela and Shafeekh, 2008). The crop species has long been used as a galactogogue to promote lactation in weaning mothers and to promote weight-gain in women (Rguibi and Belahsen 2006). Its tender leaves are consumed as leafy vegetables, while seeds are used as condiments and flavouring food preparations. Studies on genetic variability with the help of suitable biometrical tools such as variability, 
heritability, genetic advance gives us an idea about the extent of genetic variability present in the population. Burton and Devene (1952) suggested that genetic variability along with heritability should be considered for assessing the maximum and accurate effect of selection. Johnson et al., (1955) reported that heritability and genetic advance, when computed together, are more useful in predicting the resultant effect of selection. The most important among attributes of plant is its ability to yield, for rational approach of improvement of yield.

\section{Materials and Methods}

Forty genotypes of fenugreek including two check entries viz. GM 1 and GM 2 (Table 1) received from Seed Spices Research Station, S. D. Agricultural University, Jagudan and evaluated at the agronomy instructional farm, Sardarkrushinagar, North Gujarat during rabi2019. The experiment was laid out in a Randomized Block Design with four replications. Each genotype was represented in two rows of 4.0 meter length placed with $45 \mathrm{~cm}$ and $10 \mathrm{~cm}$ inter and intra row distance, respectively. Five competitive plants was selected randomly from each replication of each plot and recorded the observation on average basis for seed yield per plant, plant height, days to flowering, days to maturity, number of branches per plant, number of pods per plant, pod length, number seeds per pod, test weight and harvest index.

Analysis of variance in respect of various characters were estimated according to the formula given by Panse and Sukhatme(1978), PCV and GCV were computed based on the methods given by Burton (1952). The coefficients of variation were categorized as proposed by Sivasubramanian and Madhava Menon (1973). The heritability was computed based on the method given by Allard (1960). Genetic advance and genetic advance as percentage of mean were estimated according to the formula given by Johnson et al., (1955).

\section{Results and Discussion}

Analysis of variance showed significant differences among the genotypes for all the characters studied. The variability parameters are presented in Table-2. The estimates of genotypic and phenotypic variances revealed that all the characters showed predominance of genotypic variance in total phenotypic variance. So, expression of such characters showed low influence of environmental factors.

The traits number of branches per plant, number of pods per plant, seed yield per plant and harvest index showed high GCV and PCV values suggested considerable scope for improvement of these traits by selection. Moderate GCV and high PCV were recorded for number of seeds per and pod length. Low GCV and PCV were recorded for plant height, days to flowering and days to maturity.

Similar results was also obtained by Prakash et al., (2020) for number of branches per plant, Bhatt et al., (2019) for seed yield per plant, Verma and Ali (2012) for harvest index, plant height and days to flowering, Mamatha et al., (2017) for days to flowering and days to maturity and number of seeds per pod. for test weight was recoreded by Kole and Saha (2013).

High values of heritability in broad sense are helpful in identifying the appropriate character for selection and in enabling the breeder to select superior genotypes on the basis of phenotypic expression and its utilization in future breeding programme. High heritability was observed for traits viz., plant height, days to flowering, days to maturity, number of branches per plant, 
number of pods per plant, pod length, number of seeds per pod, test weight, seed yield per plant and harvest index. Similar results were recorded by Bhatt et al., (2019) and Prakash et al., (2020).

Table.1 List of Fenugreek [Trigonella foenum-graecum (L.)] genotypes used in the research

\begin{tabular}{|c|c|c|c|c|c|c|c|}
\hline $\begin{array}{c}\text { Sr. } \\
\text { No. }\end{array}$ & Genotypes & $\begin{array}{c}\text { Sr. } \\
\text { No. }\end{array}$ & Genotypes & $\begin{array}{c}\text { Sr. } \\
\text { No. }\end{array}$ & Genotypes & Sr. No. & Genotypes \\
\hline $\mathbf{1}$ & JFg 224 & 11 & HM 257 & 21 & JFg 13 & 31 & JFg 183 \\
\hline $\mathbf{2}$ & JFg 268 & 12 & HM 425 & 22 & JFg 15 & 32 & JFg 184 \\
\hline $\mathbf{3}$ & UM 126 & 13 & RM 204 & 23 & JFg 77 & 33 & JFg 185 \\
\hline $\mathbf{4}$ & UM 294 & 14 & PM 1 & 24 & JFg 80 & 34 & JFg 191 \\
\hline $\mathbf{5}$ & LFC 72 & 15 & Hisar Sonali & 25 & JFg 52 & 35 & JFg 194 \\
\hline $\mathbf{6}$ & LFC 90 & 16 & RMT 361 & 26 & JFg 148 & 36 & JFg 195 \\
\hline $\mathbf{7}$ & AFG 7 & 17 & FGK 138 & 27 & JFg 178 & 37 & JFg 196 \\
\hline $\mathbf{8}$ & AFG 8 & 18 & JFg 13-04 & 28 & JFg 179 & 38 & Kasuri methi \\
\hline $\mathbf{9}$ & NDM 79 & 19 & Anantpur & 29 & JFg 180 & 39 & GM 1 (C) \\
\hline $\mathbf{1 0}$ & NDM 82 & 20 & JFg 7 & 30 & JFg 181 & 40 & GM 2 (C) \\
\hline
\end{tabular}

Table.2 Estimates of variability and genetic parameters for ten characters in fenugreek

\begin{tabular}{|c|c|c|c|c|c|c|c|c|c|c|}
\hline $\begin{array}{c}\text { Character } \\
\text { s }\end{array}$ & $\begin{array}{c}\text { Seed } \\
\text { yield per } \\
\text { plant (g) }\end{array}$ & $\begin{array}{c}\text { Plant } \\
\text { height } \\
(\mathbf{c m})\end{array}$ & $\begin{array}{c}\text { Days to } \\
\text { floweri } \\
\text { ng }\end{array}$ & $\begin{array}{l}\text { Days to } \\
\text { maturit } \\
y\end{array}$ & $\begin{array}{c}\text { No. of } \\
\text { Branc } \\
\text { hes } \\
\text { per } \\
\text { plant }\end{array}$ & $\begin{array}{c}\text { No. of } \\
\text { pods per } \\
\text { plant }\end{array}$ & $\begin{array}{l}\text { Pod } \\
\text { length } \\
\text { (cm) }\end{array}$ & $\begin{array}{l}\text { No. of } \\
\text { seeds } \\
\text { per } \\
\text { pod }\end{array}$ & $\begin{array}{c}\text { Test } \\
\text { weight } \\
\text { (g) }\end{array}$ & $\begin{array}{c}\text { Harvest } \\
\text { index }(\%)\end{array}$ \\
\hline Mean & 8.81 & 68.02 & 54.79 & 126.59 & 4.94 & 45.43 & 11.22 & 12.67 & 14.90 & 32.96 \\
\hline Range & $\begin{array}{l}5.52- \\
13.61\end{array}$ & $\begin{array}{c}55.47- \\
77.43\end{array}$ & $\begin{array}{c}49.50- \\
70.50\end{array}$ & $\begin{array}{c}118.75- \\
144.00\end{array}$ & $\begin{array}{c}2.33- \\
8.31\end{array}$ & $\begin{array}{l}28.10- \\
126.06\end{array}$ & $\begin{array}{l}1.73- \\
14.60\end{array}$ & $\begin{array}{l}4.46- \\
15.90\end{array}$ & $\begin{array}{l}9.73- \\
17.96\end{array}$ & $\begin{array}{c}19.87- \\
51.99\end{array}$ \\
\hline$\sigma^{2} g$ & 4.92 & 33.95 & 24.50 & 25.38 & 2.34 & 261.57 & 4.18 & 4.29 & 2.44 & 63.29 \\
\hline$\sigma^{2} p$ & 6.11 & 43.76 & 27.51 & 30.49 & 2.51 & 281.80 & 5.63 & 5.57 & 2.74 & 73.47 \\
\hline$\sigma^{2} \mathrm{e}$ & 1.18 & 9.81 & 3.00 & 5.11 & 0.16 & 22 & 1.44 & 1.28 & 0.30 & 10.17 \\
\hline GCV (\%) & 25.19 & 8.56 & 9.03 & 3.98 & 31.00 & 35.60 & 18.23 & 16.35 & 10.48 & 24.13 \\
\hline PCV (\%) & 28.07 & 9.72 & 9.57 & 4.36 & 32.07 & 36.95 & 21.14 & 18.63 & 11.12 & 26.00 \\
\hline $\mathbf{H}^{2}$ & 80.57 & 77.58 & 89.08 & 83.24 & 93.48 & 92.82 & 74.37 & 76.97 & 88.94 & 86.14 \\
\hline $\begin{array}{c}\text { GA }(\% \\
\text { mean) }\end{array}$ & 46.59 & 15.54 & 17.56 & 7.48 & 61.76 & 70.66 & 32.39 & 29.55 & 20.37 & 46.15 \\
\hline S.Em. & 0.545 & 1.566 & 0.867 & 1.130 & 0.202 & 2.249 & 0.601 & 0.567 & 0.275 & 1.595 \\
\hline $\begin{array}{c}\text { C.D. at } \\
\mathbf{5 \%}\end{array}$ & 1.51 & 4.34 & 2.40 & 3.13 & 0.56 & 6.23 & 1.66 & 1.57 & 0.76 & 4.42 \\
\hline C.V.\% & 12.373 & 4.605 & 3.164 & 1.786 & 8.189 & 9.900 & 10.702 & 8.944 & 3.698 & 9.680 \\
\hline
\end{tabular}

The high heritability coupled with high genetic advance as percent of mean indicated that heritability in genotypes were due to additive gene effects indicating better scope for the improvement in the characters by effective selection of genotypes. The traits number of branches per plant, number of pods per plant, pod length, number of seeds per 
pod, test weight, seed yield per plant and harvest index were exhibited high heritability with high genetic advance percent of mean which could be effectively improved by selection. The results are close with Prakash et al., (2020) and Bhatt et al., (2019).

The high heritability and moderate genetic advance as percent of mean indicates that heritability in genotype were due to additive gene effect indicating better scope for the improvement in the character by effective selection of genotypes. The traits plant height and days to flowering showed high heritability and moderate genetic advance as percent of mean. Similar results for plant height was concluded by Prajapati et al., (2010) and for days to flowering similar results was given by Hosamath et al., (2017). The high heritability and low genetic advance as percent of mean was observed in days to maturity same results recorded by Prajapati et al., (2010) and Mamatha et al., (2017).

The characters such as seed yield per plant, number of branches per plant, number of pods per plant and harvest index exhibited high GCV (\%), heritability as well as genetic advance and hence, these characters being governed by additive gene action. The phenotypic selection which make use of additive genetic variance would be effective for genetic improvement of these traits (Poneleit and Bauman, 1970). Alternate systems like biparental mating (Moll and Robinson, 1967), crossing of selected sibs in early generation (Andrus, 1963) and diallel selective mating system (Jensen, 1970) followed by selection of individual plants may be adopted to improve the seed yield in this species.

\section{References}

Allard, R. W., (1960). Principles of Plant Breeding, John Wiley and Sons, Inc.,
New York. pp. 145.

Andrus, C.F. (1963). Plant breeding systems. Euphytica, 12: 205-228.

Anonymous (2019). Department of Agriculture, Cooperation \& Farmers Welfare, New Delhi.

Bhatt, B., Raghav, M., Jeena, A. S., Agrawal, S. and Gaur, A. K. (2019). Assessment of genetic variability of fenugreek [Trigonella foenum-graecum (L.)] genotypes under Tarai conditions of Uttarakhand. International Journal of Current Science. 7 (4): 484-487.

Burton, G. W. and E. H. Devene (1952). Estimating heritability in tall fescue (Festeca arundina Ceae) from replicated clonal material. Agronomy Journal. 45: 478-481.

Burton, G.W. (1952). Quantitative inheritance in grasses. Proc. $6^{\text {th }}$ Int. Grassland Congress, 1:277.

Jensen, N.F.(1970). A diallel selective mating system for cereal breeding. Crop Science.10: 629-635.

Johnson, H. W., H. F. Robinson and Comstock, R. E. (1955). Genotypic and phenotypic correlation in soybean and their implication in selection. Agronomy Journal. 47: 477-483.

Kole, P. C. and Saha, A. (2013). Studies on variability and heritability for different quantitative characters in fenugreek under different environments. Journal of Plant Breeding and crop science. 5 (11): 224-228.

Leela, N. K. and Shafeekh, K. M. (2008). Fenugreek. Chemistry of spices. 242259.

Mamatha, N. C., Tehlan, S. K., Srikanth, M., Ravikumar, T., Batra, V. K., Reddy, K. P. and Kumar, M. (2017). Variability Studies for Yield and Its Attributing Traits in Fenugreek [Trigonella foenumgraecum (L.)] Genotypes. International Journal of Pure and Applied Bioscience. 5 (3): 1075-1079. 
Moll, R.H and Robinson, H.F. (1967). Quantitative genetic investigation of yield of maize, Zuchter, 37 : 192- 199.

Panse, V. G. and P. V. Sukhatme (1978). Statistical methods for agricultural workers. ICAR, New Delhi. pp. 381.

Poneleit, G.G. and Bauman, L.F. (1970). Diallel analyses of fatty acids in corn (Zea mays L.) oil. Crop Science.10:338341.

Prajapati, D. B.; Ravindrababu, Y. and Prajapati, B. H. (2010). Genetic variability and character association in fenugreek [Trigonella foenum-graecum (L.)]. Journal of Spices and Aromatic Crops. 19 (1\&2):61-64.

Prakash, S., Pandey, V. P., Gautam, D. K., Bhargava, A. K. and Nath, T. (2020). Evaluation of Germplasm Genetic Variability, Heritability and Genetic Advance in Fenugreek [Trigonella foenum-graecum (L.)]. International
Journal of Current Micrbiology and Apllied Science. 9 (4): 303-308.

Rguibi, M. and Belahsen, R. (2006). Fattening practices among Moroccan Saharawi women. Eastern Mediterranean Health Journal. 12 (5): 619-624, 2006.

Tiran, D. (2003). The use of fenugreek for breast feeding women. Complementary Therapies in Clinical Practice. 9 (3): $155-156$.

Verma, P. and Ali, M. (2012). Genetic variability in fenugreek [Trigonella foenum- graecum (L.)] assessed in South Eastern Rajasthan. International Journal of Seed Spices. 2 (1): 56-58.

Yadav, P., Tehlan, S. K. and Kumar, M. (2018). Genetic variability and association analysis for seed yield and its components in fenugreek [Trigonella foenum- graecum (L.)]. Indian Journal of Genetics. 78 (2): 275-278.

\section{How to cite this article:}

Patel, D. K., A. M. Patel and Sundesha, D. L. 2021. Genetic Variability, Heritability and Genetic Advance for Seed Yield in Fenugreek [Trigonella foenum-graecum (L.)]. Int.J.Curr.Microbiol.App.Sci. 10(01): 3233-3237. doi: https://doi.org/10.20546/ijcmas.2021.1001.376 